\title{
Granular cell tumour of clitoris: a case report
}

\author{
Alka Goel$^{1}$, Anupriya Narain ${ }^{2 *}$, Khushboo Singh ${ }^{1}$, Minakshi Bhardwaj ${ }^{3}$
}

\author{
${ }^{1}$ Department of Obstetrics and Gynecology, PGIMER and Dr RML Hospital, New Delhi, India \\ ${ }^{2}$ Department of Obstetrics and Gynecology, Maulana Azad Medical College and Lok Nayak Hospital, New Delhi, \\ India \\ ${ }^{3}$ Department of Pathology, PGIMER and Dr RML Hospital, New Delhi, India
}

Received: 17 February 2019

Accepted: 08 April 2019

\section{*Correspondence:}

Dr. Anupriya Narain,

E-mail: anupriyanarani@gmail.com

Copyright: () the author(s), publisher and licensee Medip Academy. This is an open-access article distributed under the terms of the Creative Commons Attribution Non-Commercial License, which permits unrestricted non-commercial use, distribution, and reproduction in any medium, provided the original work is properly cited.

\begin{abstract}
Granular cell tumour (GCT) is tumours showing neuroectodermal differentiation. It occurs mostly in the dermis and subcutaneous tissue and occurrence in the muscle layer is rare. The most common site is the head and neck region. It has been known to occur in the vulva, with clitoris being a very rare site. Granular cell tumours are slow growing tumours, which are mostly asymptomatic. We report a case of lump in the clitoris in a 42-year-old woman which was managed with surgical excision. Histopathology confirmed the diagnosis of granular cell tumour. Very few cases of granular cell tumour of clitoris have been reported in literature till date. Although mostly benign, the differential diagnosis of granular cell tumour should be borne in mind by the clinicians in cases of clitoral lump.
\end{abstract}

Keywords: Clitoris, Granular cell tumour, Reproductive age group

\section{INTRODUCTION}

Granular cell tumour is an uncommon entity accounting for only $0.5 \%$ of all soft tissue tumours. ${ }^{1}$ These tumours are of benign nature in $98 \%$ cases, only $2 \%$ being malignant. ${ }^{2}$ The granular cell tumours are more common in black women. ${ }^{3}$ Around $7-15 \%$ of all granular cell tumours occur in the vulva with labium majus being the most common site. ${ }^{4,5}$ There have also been reported cases involving the ovary, uterus, cervix, vagina, mons pubis and episiotomy scar. Granular cell tumour of clitoris is a rare phenomenon. Surgical excision remains the mainstay of treatment. In the malignant varieties, adjuvant chemoradiation is suggested although the response is poor. Although the origin of granular cell tumour remains an enigma, the origin from schwann cells has been proposed as the most appropriate. We report a rare case of granular cell tumour of clitoris in a female of reproductive age group with the appropriate surgical approach.

\section{CASE REPORT}

A 42 year old woman presented with complaints of an asymptomatic lump in the clitoris. She had been observing the lump for the past 3-4 months which was painless, did not grow in size and caused no trouble. However, the patient was apprehensive of the location and nature of the lump and requested its removal. On examination, a small approximately $1.5 \mathrm{~cm}$ firm supple mass was felt in the body of clitoris which had smooth well defined margins and was non tender. Patient had normal menstrual cycles. She had two normal vaginal deliveries and was otherwise healthy with no other significant past medical or surgical history. Based on these findings we made the first clinical diagnosis of a clitoral fibroid.

She was posted for excision of the lump in the postmenstrual phase. The decision was taken to approach the clitoral lump from ventral aspect in order to avoid the 
neurovascular structures on the dorsal side. A small incision was given on the ventral surface after fixing the lump from dorsal side with the finger of the other hand. The lump was held with allis forceps and dissected out using mosquitoes and metzenbaum scissors. The lump was sent for histopathological examination. The post operative period was uneventful. The histopathology report confirmed the diagnosis as granular cell tumour. The patient was followed up for one year with no recurrence.

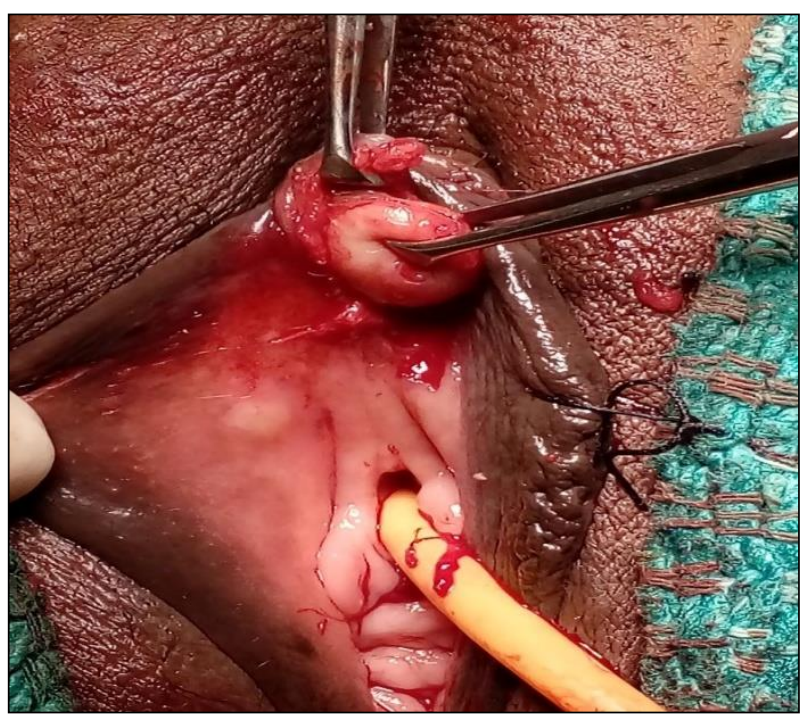

Figure 1: A $1.5 \times 1.5 \mathrm{~cm}$ mass at the clitoris.

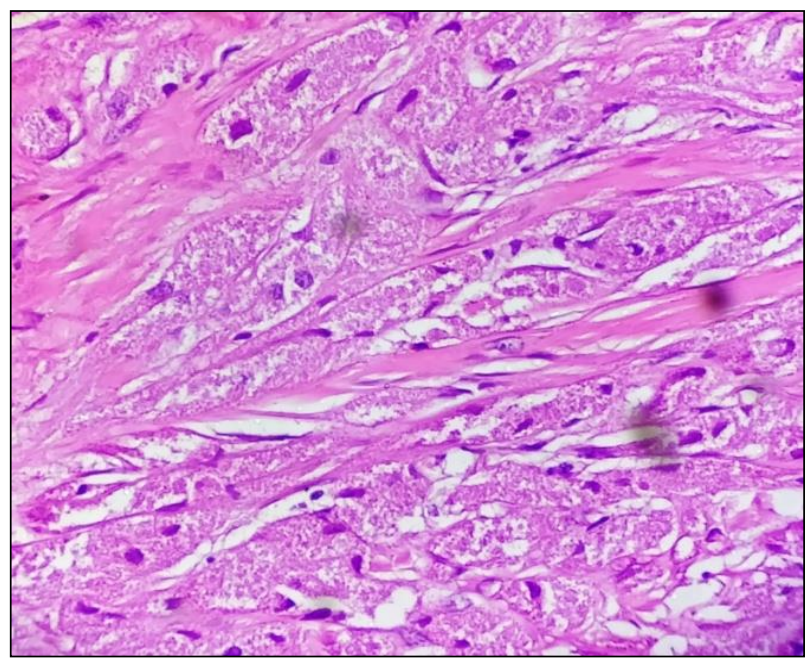

Figure 2: Histopathology of specimen showing abundant granular eosinophilic cytoplasm.

\section{DISCUSSION}

WHO defines granular cell tumour as a benign tumour showing neuroectodermal differentiation. It is composed of large oval to round cells with copious eosinophilic, distinctly granular cytoplasm. The granular appearance is due to the accumulation of lysosomes. GCTs have male to female ratio of 1:4, and have higher incidence in the fourth to fifth decade. Granular cell tumours are found in skin, subcutaneous tissue and submucosa. The most common site is head and neck especially tongues trunk and proximal extremities. The anal and perineal regions are rare sites. Around $0.5 \%-2 \%$ of granular cell tumour are malignant with mortality up to $40 \%$. $^{2,5}$ The immunohistochemistry stains are positive for $\mathrm{S} 100$ protein, PAS, neuron-specific enolase, peripheral nerve myelin proteins and vimentin, all of which strengthen the schwannian origin.

Granular cell tumours are slow growing tumours, mostly asymptomatic. At times, they may present with pain and itching. The incidence of granular cell tumour in the vulva is around $15 \%$ and around $98 \%$ of them are benign. ${ }^{2}$ Till date, very few cases have been reported in the clitoris. Reported recurrence rate with clear margin is $2.8 \% .^{7}$ The malignant form of granular cell tumors is highly aggressive, responds poorly to radiation or chemotherapy and may sometimes have fatal outcomes where lesions are present in organs such as the lung or liver. ${ }^{8}$ Guo $\mathrm{N}$ et al, reported that surgery after isophosphamide, etoposide, and cisplatin neoadjuvant chemotherapy was successful in a GCT of the uterine cervix and there was no recurrence. ${ }^{9}$

Clinically, poor prognostic factors are rapid tumor growth, tumor size $>4 \mathrm{~cm}$, invasion into adjacent tissues, history of local recurrence, and older age. ${ }^{10}$

Differential diagnosis of clitoral lumps includes epidermoid cysts, pilonidal cysts, paraurethral cysts, dysontogenetic cysts of paramesonephric or mesonephric origin and dermal adnexal tumour. ${ }^{11}$ Non-hormonal causes of clitoromegaly include lymphoma, rhabdomyosarcoma, endodermal sinus tumour, leiomyoma, genital neurofibromatosis, and distant metastatic disease.

Golchai $\mathrm{J}$ et al, reported a case of multiple granular cell tumour present simultaneously at various sites. Hence during follow-up, extragenital areas, such as oral cavity and trunk, should also be evaluated. ${ }^{12}$

Funding: No funding sources

Conflict of interest: None declared

Ethical approval: Not required

\section{REFERENCES}

1. Porta N, Mazzitelli R, Cacciotti J, Cirenza M, Labate A, Grazia M, et al. A case report of a rare intramuscular granular cell tumor. Diagn Pathol. 2015;10:162.

2. Elkousy H, Harrelson J, Dodd L, Martinez S, Scully S. Granular cell tumors of the extremities. Clin Orthop Relat Res. 2000;(380):191-8.

3. Ji-Won Min and Yun-Sook Kim. Granular cell tumor of the clitoris. J Menopausal Med. 2017;23:135-7. 
4. Degefu S, Dhurandhar HN, O'Quinn AG, Fuller PN. Granular cell tumor of the clitoris in preg-nancy. Gynecol Oncol. 1984;19(2):246-51.

5. Althausen AM, Kowalski DP, Ludwig ME, Curry SL, Greene JF. Granular cell tumors: a new clinically important histologic finding. Gynecol Oncol. 2000;77:310-3.

6. Torrijos-Aguilar A, Alegre-de Miguel V, PitarchBort G, Mercader-García P, Fortea-Baixauli JM. Cutaneous granular cell tumor: a clinical and pathologic analysis of 34 cases. Actas Dermosifiliogr. 2009;100:126-32.

7. Goel G, Singh N, Gupta R, Jain S. Recurrent benign cutaneous granular cell tumor: A case report. J Cytol. 2013;30:287-08.

8. Schmidt O, Fleckenstein G.H, Gunawan B, Fuzesi L, Emons G. Recurrence and rapid metasta-sis formation of a granular cell tumor of the vulva. Eur J Obstet Gynecol Reprod Biol. 2003;106:219-21.

9. Guo N, Peng Z, Yang K, Lou J. Uterine cervical malignant granular cell tumor. J Obstet Gynaecol Res. 2012;38:944-7.
10. Dupuis C, Coard KC. A review of granular cell tumours at the University Hospital of the West Indies: 1965-2006. West Indian Med J. 2009;58:13841.

11. Nasit JG, Chauhan S, Dhruva G. Granular cell tumor of hand presenting as subcutaneous nodule mimicking dermal adnexal tumor: A diagnosis by cytology. Indian Dermatol Online J. 2013;4:33-6.

12. Golchai J, Zargari O, Paknejadi MB. Multiple granular cell tumor in a teenager: Report of a case and review of the literature. Acta Med Iran. 2004;42:228-31.

Cite this article as: Goel A, Narain A, Singh K, Bhardwaj M. Granular cell tumour of clitoris: a case report. Int J Reprod Contracept Obstet Gynecol 2019;8:2146-8. 